\title{
CCL13 wt Allele
}

National Cancer Institute

\section{Source}

National Cancer Institute. CCL13 wt Allele. NCI Thesaurus. Code C49712.

Human CCL13 wild-type allele is located in the vicinity of $17 q 11.2$ and is approximately 2 $\mathrm{kb}$ in length. This allele, which encodes C-C motif chemokine 13 protein, plays a role in immune cell chemotaxis and signal transduction. CCL13 allelic variants may also be involved in atherosclerosis. 